кандидат педагогічних наук, доцент

(Житомирський державний університет імені Івана Франка) neota@zu.edu.ua

ORCID : $0 \odot \odot \odot-\odot \odot \odot 1-6825-4697$

\title{
ВИКОРИСТАННЯ ХМАРО ОРІСНТОВАНИХ ЗАСОБІВ У НАВЧАННІ БАКАЛАВРІВ ІНФОРМАТИКИ ДЛЯ ОРГАНІЗАЦІЇ СПІЛЬНОЇ ПРОЕКТНОЇ ДІЯЛЬНОСТІ
}

У даній статті розкриваються можливості використання хмаро орієнтованих засобів у навчанні

бакалаврів інформатики для організації спільної проектної діяльності: хмаро орієнтовані

інтелектуальні карти, компілятори та автоматизовані системи для проведення змагань 3 програмування. Уточнено поняття "спільна проектна діяльність бакалаврів інформатики". Розкрито суть методу проектів з використанням хмарних сервісів. Наведено основні етапи роботи над спільним проектом бакалаврами інформатики.

Ключові слова: хмарні сервіси, хмаро орієнтовані засоби, проектна діяльність, бакалаври інформатики, навчання.

Постановка проблеми. Стрімкий розвиток інформаційно-комунікаційних технологій призводить до появи все нових технологій: мобільних, хмарних, туманних, а використання їх у навчальному процесі стає першочерговим завданням сучасних досліджень.

Аналіз навчальних планів підготовки бакалаврів інформатики дає змогу зробити висновок, що однією 3 особливостей їх підготовки $€$ робота в команді над спільними проектами [1]. Адже більшість випускників даної спеціальності йдуть працювати програмістами в IT-компанії. Для майбутніх програмістів важливим є уміння працювати в команді над спільними проектами, виконуючи при цьому різні ролі (від програміста до менеджера з управління проектами).

Аналіз основних досліджень і публікацій із зазначеної проблеми. У педагогіці та психології на сьогодні накопичено значну кількість досліджень, пов'язаних із розробкою та застосуванням хмарних технологій в різних сферах застосування, зокрема і у навчанні. Педагогічні підходи до комп'ютеризації й інформатизації навчального процесу розглянуто в працях В. Ю Бикова, Т. В. Габай, Ю. В. Горошка, Т. П. Гергей, М. І. Жалдака, Ю. І. Машбиця, А. В. Пенькова, І. П. Підласого, С. А. Ракова, Н. Ф. Тализіної та ін.

Питанням використання хмарних технологій саме в освіті присвятили багато праць такі вчені, як $\begin{array}{llll}\text { Е. І. Аблялімова, } & \text { В. Ю. Дубницький, А. М. Кобилін, } & \text { Л. М. Меджитова, } & \text { 3. С. Сейдаметова, }\end{array}$ С. Н. Сєйтвеліева, В. А. Темненко, Ю. В. Триус, В. М. Франчук, М. П. Шишкіна та ін. Тенденції розвитку хмарних технологій розглянуто у працях Н. В. Моісеєнко, М. В. Моісеєнко, О. М. Туравініної, О. В. Чорної, М. П. Шишкіної та ін.Хмарні засоби навчання інформатичних дисциплін подано в наукових розвідках О. В. Адаменко, Т. В. Бодненко, В. В. Лазорик, Л. Ф. Панченко, А. М. Стрюка, М. І. Стрюк, О. Д. Трегуба, Ю. В. Триуса, О. В. Харченко, І. О. Чемісової, В. М. Чернова та ін.

Проблемі підготовки фахівців з інформаційних технологій, у тому числі й бакалаврів інформатики, присвятили свої наукові праці такі науковці, як М. Жалдак, В. Сремєєв, Н. Морзе, В. Осадчий, О. Спірін та ін. Теоретичні засади проектної діяльності розглядають у своїх дослідженнях О. Коберник, Н. Матяш, О. Пєхота, Є. Полат, С. Сисоєва та ін.

Проте питання організації спільної проектної діяльності засобами хмаро орієнтованих технологій у підготовці бакалаврів інформатики вітчизняними науковцями не розглядалось.

Формулювання мети і завдань статті. Саме тому метою статті $є$ описати можливості хмаро орієнтованих засобів для організації проектної діяльності бакалаврів інформатики.

Виклад основного матеріалу. На думку багатьох науковців, хмарні технологї (технології хмарних обчислень) - це один із найперспективніших напрямків розвитку засобів, а також сервісів інформаційнокомунікаційних мереж [2].

Термін хмарні технології пішов від англійського словосполучення "cloud technology", так як дослівний переклад такого слова, як "cloud" означає "хмара", але в іншому розумінні це ж саме слово можна перекласти як "розсіяний" або "розподілений". Саме тому, можна сказати, що хмарні технологїце "розподілені технології", тобто дані опрацьовуються з використанням не лише одного комп’ютера, а опрацювання розподіляється по декількох комп’ютерах, що підключені до мережі Internet.

Щодо терміну "хмарні обчислення", то однозначного формулювання даного терміну в науковій літературі не існує. Різні автори пропонують описові тлумачення.

На основі аналізу літератури з даної тематики, здебільшого під хмарними обчисленнями (англ. Cloud Computing) розуміється "модель зручного мережного доступу до загального фонду обчислювальних ресурсів, які можна швидко надати за умови мінімальних управлінських зусиль та взаємодії 3 
постачальником" [2: 15].

У Міжнародному стандарті ISO/IEC 17788:2014 "Information technology - Cloud computing - Overview and vocabulary" [3] наведено таке визначення хмарних обчислень - це така парадигма, яка забезпечує доступ у мережу загальних фізичних або віртуальних ресурсів з наданням прав самообслуговування та адміністрування на вимогу.

М. П. Шишкіна та М. В. Попель у своїй праці вводять поняття "хмарних сервісів", під якими розуміють такі сервіси, які "призначені для того, щоб робити доступними користувачеві прикладне програмне забезпечення, простір для зберігання даних та обчислювальні потужності через Інтернет" [4: 75].

У Міжнародному стандарті ISO/IEC 17788:2014 "Information technology - Cloud computing - Overview and vocabulary" [3] пропонується таке визначення хмарного сервісу - це одна або декілька можливостей, що пропонуються через парадигму хмарних обчислень, і що викликаються за допомогою певного інтерфейсу.

А. М. Стрюк та М. В. Рассовицька вводять ще таке поняття, як хмаро орієнтовані ІКТ навчання, під яким розуміють "сукупність методів, засобів і прийомів діяльності, що використовуються для організації і супроводу навчального процесу, збирання, систематизації, зберігання, опрацювання, передавання, подання повідомлень i даних навчального призначення та використовують динамічний масив віртуалізованих апаратних і програмних ресурсів, доступних через мережу незалежно від термінального пристрою [5: 152].

Під хмаро орієнтованими засобами будемо розуміти такі засоби навчання, що реалізовуються засобами хмарних технологій.

Для того, щоб описати можливості використання хмаро орієнтованих засобів навчання для організації спільної проектної діяльності, визначимо для початку, що будемо розуміти під поняттям "спільна проектна діяльність".

Проектна діяльність - "самостійне здобування знань, систематизація їх, можливість орієнтуватися в інформаційному просторі, бачити проблему і приймати рішення відбувається саме через метод проекту" [6].

Л. Хоружа у своєму дослідженні дає таке визначення проектної діяльності - "це спосіб розвитку творчості, самостійності, прагнення до ідеально-перспективного перетворення світу за допомогою креативних дій i операцій у процесі створення конкретного продукту - проекту ідеального та реального" [7: 13].

На думку Уйсімбаєвої Маріям, проектна діяльність - це "конструктивна і продуктивна діяльність особистості, спрямована на розв'язання життєво значущої проблеми, досягнення кінцевого результату в процесі цілепокладання, планування і здійснення проекту" [8: 259].

У даному дослідженні під спільною проектної діяльністю бакалаврів інформатики будемо розуміти спільну діяльність декількох студентів, що спрямована на досягнення успішного результату (створення конкретного продукту) у процесі роботи над спільним проектом.

Власне метод проектів з використанням хмарних сервісів - полягає у розвитку пізнавальних і творчих навичок студентів, умінь орієнтуватися в інформаційному просторі засобами хмарних сервісів, самостійно конструювати свої знання, критично мислити [9: 133].

Наведемо основні етапи роботи над спільним проектом бакалаврами інформатики.

1) Постановка проблеми

2) Обговорення

3) Складання плану дій

4) Розподіл дій (визначення ролей)

5) Розробка проекту за складеним планом

6) Перевірка готовності

7) Представлення проекту

Власне проекти можуть бути як дослідницькі, так і суспільні, що допомагає майбутнім фахівцям навчитись працювати злагоджено у команді. Тому наведемо можливості використання різних хмаро орієнтованих засобів на усіх етапах роботи над спільним проектом.

\section{Використання хмаро оріснтованих інтелектуальних карт.}

Побудова інтелект-карт для спільних проектів полегшує розподіл обов'язків між усіма учасниками проекту, визначення структури проекту, завдань, етапів реалізації даного проекту; стимулює студентів до генерації власних ідеї та їх аналізі, узгодження спільного рішення. Наприклад, у 3 турі конкурсу Завтра.UA фонду Віктора Пінчука студентам потрібно в обмежений час реалізувати спільний проект, а також представити його членам журі. Щоб проект був представлений максимально якісно та відображав ідеї усіх учасників проекту варто використовувати хмарні сервіси для побудови ментальних карт (див. рис. 1). 


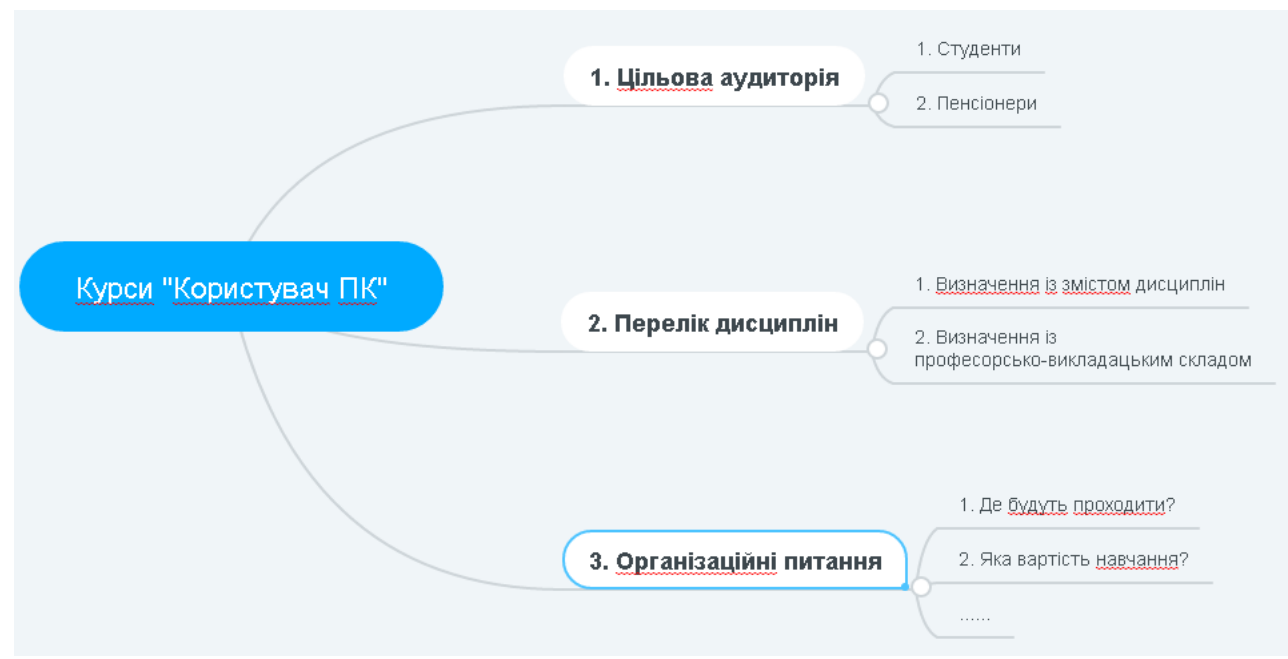

Рис. 1. Інтелектуальна карта "Спільний проект".

\section{Використання хмаро орієнтованих компіляторів}

Використання хмаро орієнтованих компіляторів дає свої переваги. Наприклад, AWS Cloud 9 - це хмарне середовище розробки, яке дає змогу створювати, запускати та налагоджувати код. Дане середовище підтримує такі мови програмування, як JavaScript, Python, PHP та ін. До переваг даного середовища варто віднести можливість працювати одночасно усіма членами команди, програмувати одночасно з колегами, навіть не виходячи 3 дому, а також у режимі реального часу відслідковувати код, який був доданий іншими членами команди (див. рис. 2).

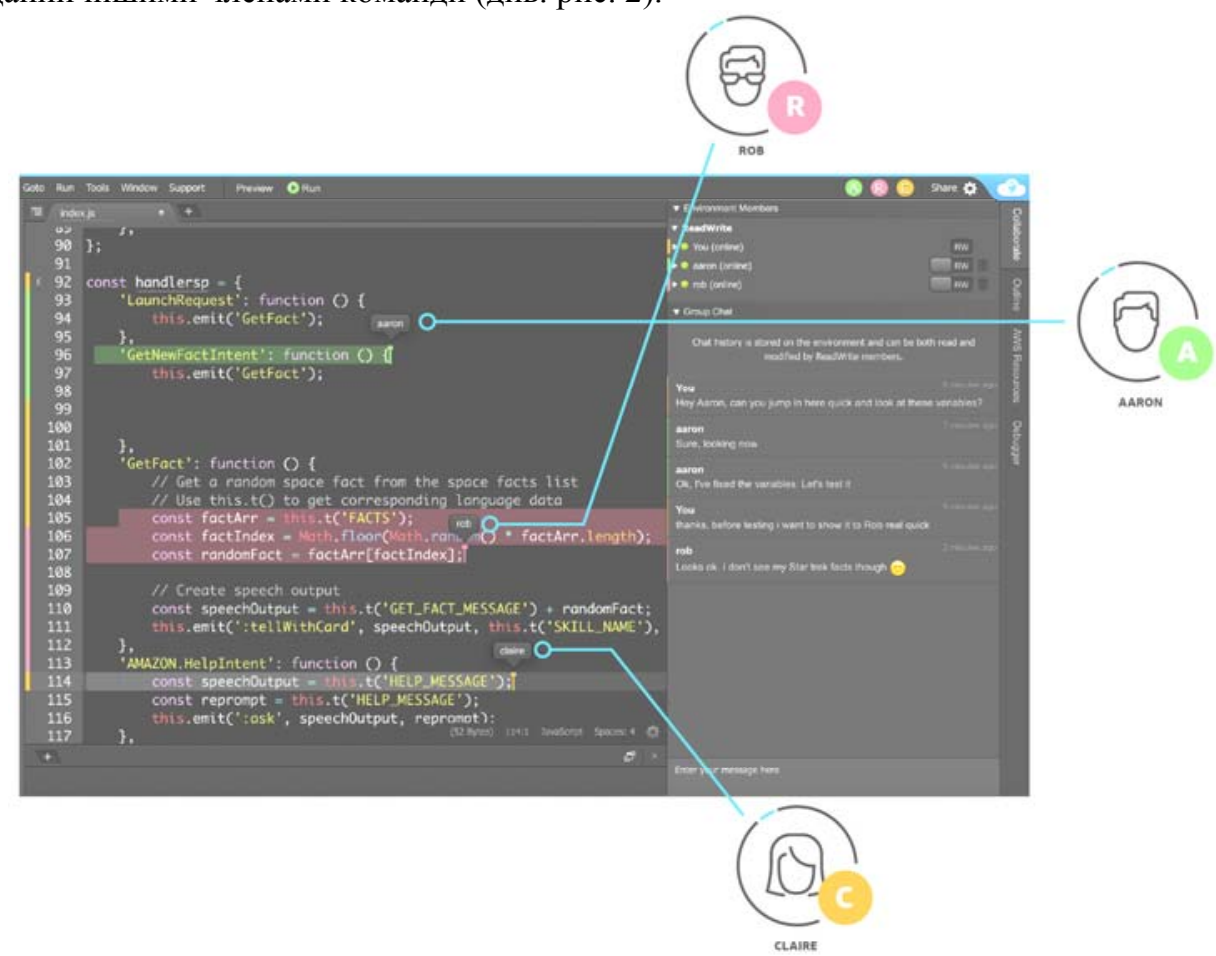

Рис. 2. Хмарне середовище розробки коду AWS Cloud 9

Перелічені можливості даного компілятора $є$ зручними саме для створення спільного проекту або для підготовки до командних змагань, де декілька осіб працюють над одним завданням.

\section{Використання хмаро орієнтованих автоматизованих систем для проведення змагань 3 програмування}

Зауважимо, що у практиці програмної інженерії робота над спільним проектом означає забезпечення моделі життєвого циклу програмного продукту. Модель життєвого циклу - "це схема виконання робіт і задач у рамках процесів, що забезпечують розробку, експлуатацію і супровід програмного продукту" [10]. Зазвичай, така схема робіт містить у собі: розробку вимог або технічного завдання; розробку 
ескізного або технічного проекту; програмування або робоче проектування; пробну експлуатацію; супровід і поліпшення; зняття з експлуатації [10]. Для того, щоб студенти навчились діяти на кожному 3 етапів, варто застосовувати web-орієнтовану автоматизовану систему TopCoder.

TopCoder - web-орієнтована автоматизована система, що створена для регулярної організації та проведення змагань $з$ програмування.

Змагання, що пропонуються у даній системі, $є$ не лише 3 алгоритмічного програмування, а й 3 : розробки дизайну програмного забезпечення, концептуалізації П3, специфікації, архітектури ПЗ, девелопменту, зведення, тестування, а також міні-змагання щодо виявлення помилок (див. рис. 3 ).

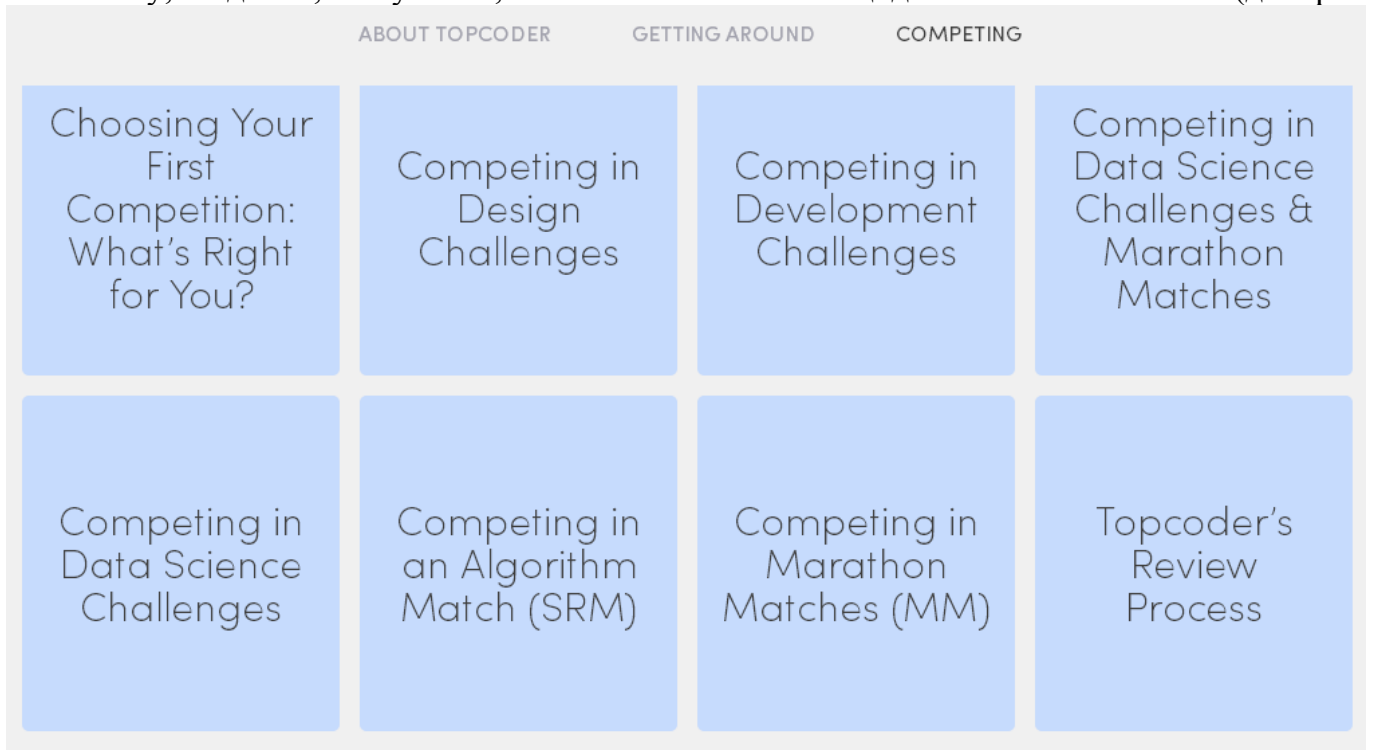

Puc. 3. Tипи змагань у TopCoder

Розглянемо більш детально кожен з перелічених видів змагань.

1) Змагання 3 алгоритмічного програмування - забезпечують проведення змагань для перевірки рівня знань, умінь та навичок з алгоритмічного програмування будь-якою мовою програмування.

2) Змагання з розробки дизайну програмного забезпечення - полягають у розробці дизайну до конкретного розробленого програмного забезпечення, вимоги та всі необхідні ключові моменти надає уявний замовник.

3) Змагання 3 концептуалізації програмного забезпечення - полягає у створенні бізнес-вимог для продукту у межах співпраці із безпосередніми замовниками програмного забезпечення.

4) Змагання зі специфікації програмного забезпечення - полягає у створенні формальної документації по проекту із документів, наданих уявними клієнтами, замовниками.

5) Змагання 3 архітектури програмного забезпечення - створення архітектури програмного забезпечення із виділенням окремих функціональних компонентів за отриманою документацією від безпосереднього замовника або отриманих в результаті вже проведених змагань.

6) Змагання з девелопменту - розробка окремої функціональної компоненти згідно заявлених вимог клієнта.

7) Змагання зі зведення - це окремий вид змагань, який передбачає зведення продукту по розробленим окремим компонентам в єдине ціле.

8) Змагання з тестування розробленого програмного забезпечення - вид змагань, в якому тестують уже розроблене програмне забезпечення у раніше проведених змаганнях.

9) Міні-змагання щодо виявлення помилок у готовому коді.

Зауважимо, що дані змагання у комплексі забезпечують розвиток умінь та навичок працювати у команді на всіх етапах розробки ПЗ, що є важливим у майбутній професії програміста. А широкий різновид змагань забезпечує уміння працювати в команді у різних ролях: від тестувальника до менеджера проектів.

Висновки та перспективи подальшого дослідження проблеми. Отже, як показує дослідження, для ефективної організації спільної проектної діяльності є використання різних хмаро орієнтованих засобів навчання бакалаврів інформатики: інтелектуальних карт, компіляторів та автоматизованих систем для проведення змагань з програмування.

Подальшими перспективами є розробка цілісної методики використання хмаро орієнтованих засобів у навчанні бакалаврів інформатики. 


\section{СПИСОК ВИКОРИСТАНИХ ДЖЕРЕЛ ТА ЛІТЕРАТУРИ}

1. Вакалюк Т. А. Особливості та специфіка підготовки бакалаврів інформатики / Т. А. Вакалюк // Проблеми підготовки сучасного вчителя : [збірник наукових праць Уманського державного педагогічного університету імені Павла Тичини] / [ред. кол. : Безлюдний О. І. (гол. ред.) та ін.]. - Умань : ВПЦ Візаві, 2017. - Випуск 16. -319 c. - C. $28-35$.

2. Биков В. Ю. Технології хмарних обчислень, ІКТ-аутсорсінг та нові функції ІКТ підрозділів освітніх і наукових установ / В. Ю. Биков // Інформаційні технології в освіті. - № 10. - 2011. - С. 8-23.

3. ISO/IEC 17788:2014 "Information technology - Cloud computing - Overview and vocabulary" [Electronic Resourse] / Online Browsing Platform (OBP). - Mode of access : https://www.iso.org/obp/ui/\#iso:std:isoiec:17788:ed-1:v1:en.

4. Шишкіна М. П. Хмаро орієнтоване освітнє середовище навчального закладу: сучасний стан і перспективи розвитку досліджень [Електронний ресурс] / М. П. Шишкіна, М.В.Попель // Інформаційні технології і засоби навчання. - 2013. - № 5(37). - С. 66-80. - Режим доступу до журн. : http://journal.iitta.gov.ua/index.php/itlt/article/view/903/676.

5. Стрюк А. М. Система хмаро орієнтованих засобів навчання як елемент інформаційного освітньо-наукового середовища ВНЗ [Електронний ресурс] / А. М. Стрюк, М. В. Рассовицька // Інформаційні технології і засоби навчання. - 2014. - № 4(42). - С. 150-158. - Режим доступу до журн. : http://journal.iitta.gov.ua/index.php/itlt/article/view/1087/829.

6. Проектна діяльність [Електронний ресурс]. - Режим доступу : http://ukped.com/skarbnichka/396.html.

7. Хоружа Л. Проектна культура вчителя: етичний компонент / Л. Хоружа // Шлях освіти. - 2006. - № 4. C. $11-15$.

8. Уйсімбаєва Маріям Проектна діяльність : теоретичні аспекти / Маріям Уйсімбаєва // Витоки педагогічної майстерності. - 2014. - Випуск 13. - С. 258-263.

9. Буйницька О. П. Інформаційні технології та технічні засоби навчання : [навчально-методичний посібник для самостійного вивчення курсу]. - Кам’янець-Подільський : ПП Буйницький, 2009. - 240 с.

10. Концедайло В. В. Інструктивно-методичні матеріали до практичних занять 3 курсу "Професійна практика програмної інженерії" / В. В. Концедайло, Т. А. Вакалюк. - Житомир : вид-во ФОП "О. О. Євенок", 2018. $60 \mathrm{c}$.

\section{REFERENCES (TRANSLATED \& TRANSLITERATED)}

1. Vakaliuk T. A. Osoblyvosti ta spetsyfika pidhotovky bakalavriv informatyky [Features and Specifics of Bachelor's Degree in Computer Science] / T. A. Vakaliuk // Problemy pidhotovky suchasnoho vchytelia [Problems of Preparing a Modern Teacher] : [zbirnyk naukovykh prats' Umans'koho derzhavnoho pedahohichnoho universytetu imeni Pavla Tychyny / [red. kol. : Bezliudnyi O. I. (hol. red.) ta in.]. - Uman' : VPTs Vizavi, 2017. - Vypusk 16. - 319 s. - S. 28-35.

2. Bykov V. Yu. Tekhnolohii khmarnykh obchyslen, IKT-autsorsinh ta novi funktsii IKT pidrozdiliv osvitnikh i naukovykh ustanov [Cloud Computing Technologies, ICT Outsourcing and New ICT Functions of Educational and Research Institutions] / V. Yu. Bykov // Informatsiini tekhnolohii v osviti [Information Technologies in Education]. - № 10. - 2011. - S. 8-23.

3. ISO/IEC 17788:2014 "Information technology - Cloud computing - Overview and vocabulary" [Electronic Resourse] / Online Browsing Platform (OBP). - Mode of access : https://www.iso.org/obp/ui/\#iso:std:isoiec:17788:ed-1:v1:en.

4. Shyshkina M. P. Khmaro oriientovane osvitnie seredovyshche navchal'noho zakladu : suchasnyi stan i perspektyvy rozvytku doslidzhen [The Cloud-based Educational Environment of an Educational Institution: the Current State and Prospects of Research Development] [Elektronnyi resurs] / M. P. Shyshkina, M. V. Popel // Informatsiini tekhnolohii i zasoby navchannia [Information Technologies and Learning Tools]. - 2013. - № 5 (37). - S. 66-80. Rezhym dostupu do zhurn. : http://journal.iitta.gov.ua/index.php/itlt/article/view/903/676.

5. Striuk A. M. Systema khmaro oriientovanykh zasobiv navchannia yak element informatsiinoho osvitno-naukovoho seredovyshcha VNZ [The System of Cloud-oriented Teaching Aids as an Element of the Information Educational and Scientific Environment of the University] [Elektronnyi resurs] / A. M. Striuk, M. V. Rassovytska // Informatsiini tekhnolohii i zasoby navchannia [Information Technologies and Learning Tools]. - 2014. - № 4 (42). - S. 150-158. - Rezhym dostupu do zhurn. : http://journal.iitta.gov.ua/index.php/itlt/article/view/1087/829.

6. Proektna diial'nist [Project Activity] [Elektronnyi resurs]. - Rezhym dostupu : http://ukped.com/skarbnichka/396.html.

7. Khoruzha L. Proektna kul'tura vchytelia : etychnyi komponent [The Design Culture of the Teacher: the Ethical Component] / L. Khoruzha // Shliakh osvity [Education Path]. - 2006. - № 4. - S. 11-15.

8. Uisimbaieva Mariiam. Proektna diial'nist: teoretychni aspekty [Project Activity: Theoretical Aspects] // Vytoky pedahohichnoi maisternosti [Origins of Pedagogical Skill]. - 2014. - Vypusk 13. - S. 258-263.

9. Buinytska O. P. Informatsiini tekhnolohii ta tekhnichni zasoby navchannia [Information Technology and Technical Means of Training] : [navchal'no-metodychnyi posibnyk dlia samostiinoho vyvchennia kursu]. - KamianetsPodilskyi : PP Buinytskyi, 2009. - 240 s.

10. Kontsedailo V. V. Instruktyvno-metodychni materialy do praktychnykh zaniat' $z$ kursu "Profesiina praktyka prohramnoi inzhenerii" [Instructional and Methodical Materials for Practical Lessons on "Professional Practice of Software Engineering"] / Kontsedailo V. V., Vakaliuk T. A.. - Zhytomyr : vyd-vo FOP "O.O.Ievenok", 2018. $60 \mathrm{~s}$. 


\section{Вакалюк Т. А. Использование облако ориентированных средств в обучении бакалавров} информатики для организации совместной проектной деятельности.

В данной статье раскрываются возможности использования облако ориентированных средств 8 обучении бакалавров информатики для организации совместной проектной деятельности: облако

ориентированы интеллектуальные карты, компиляторы и автоматизированные системы для проведения соревнований по программированию. Уточнено понятие "общая проектная деятельность бакалавров информатики". Раскрыта суть метода проектов с использованием облачных сервисов.

Приведены основные этапы работы над совместным проектом бакалаврами информатики.

Ключевые слова: облачные сервисы, облако ориентированные средства, проектная деятельность, бакалавры информатики, обучение.

\section{Vakaliuk T. A. Using of Cloud-Oriented Means during the Training Bachelors of the Computer Science for the Organization of Joint Project Activities.}

It has been established that the rapid development of information and communication technologies leads to the emergence of new technologies such as: mobile, cloudy, foggy. Their use in the educational process becomes a priority task of the modern research. An analysis of the curriculum for the preparation of bachelor's degrees in computer science allowed us to conclude that one of the peculiarities of their preparation is work in the team with joint projects. This article explores the possibilities of using cloud-oriented means in the training of bachelors of computer science for the organization of joint project activities: cloud-oriented intelligent maps, compilers and automated systems for programming competitions. In the article the following concepts such as

"joint project activity of bachelors of computer science", "cloud technologies", "cloud computing", "cloud services", "cloud-oriented means" are specified. The essence of the method of projects with using cloud services is revealed by author.

The main stages of work on a joint project of bachelor of the computer science are described. The author emphasized that development of skills and abilities to work in the team at all stages of software development are very important in the future programmer profession. It can be realized during various types of competitions with using the automated system for programming, for example TopCoder. A wide variety of competitions provides the ability to team-work in different roles (from the testator to the project manager).

Key words: cloud services, cloud-oriented means, project activity, bachelors of computer science, training. 